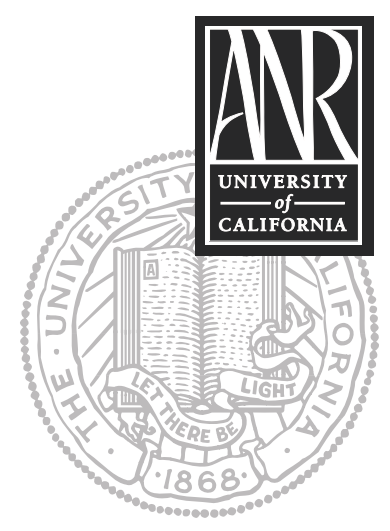

UNIVERSITY OF CALIFORNIA

Division of Agriculture and Natural Resources http://anrcatalog.ucdavis.edu

\title{
Conservation Tillage and Weed Management
}

ANIL SHRESTHA, IPM Weed Ecologist, Statewide IPM Program; TOM LANINI, Weed Ecologist, UC Davis; STEVE WRIGHT, UC Cooperative Extension Farm Advisor, Tulare County; RON VARGAS, UCCE Farm Advisor, Madera and Merced Counties; and JEFF MITCHELL, Cropping Systems Specialist, UC Davis

Tillage has long been an essential component of traditional agricultural systems. Broadly defined, tillage is the mechanical manipulation of the soil and plant residues to prepare a seedbed for crop planting. The benefits of tillage are many: it loosens soil, enhances the release of nutrients from the soil for crop growth, kills weeds, and regulates the circulation of water and air within the soil (Reicosky and Allmaras, 2003). In some cases, however, intensive tillage has been found to adversely affect soil structure and cause excessive breakdown of aggregates, leading to soil erosion in higher-rainfall areas. Intensive tillage can also have a negative impact on environmental quality by accelerating soil carbon loss and greenhouse gas emissions (Reicosky and Allmaras, 2003). Further, tillage operations account for more than 25 percent of agricultural production costs (Carter, 1996). With recent increases in fuel prices, tillage now accounts for a higher proportion of production costs than harvesting does (Edwards and Smith, 2005). Such concerns have fueled interest in finding tillage systems that minimize negative impacts to the environment while sustaining economic crop productivity.

The tillage systems being developed and studied to address these concerns can broadly be termed conservation tillage (CT). In California, conventional tillage practices face additional challenges as population centers expand into farming areas and new residents raise serious concerns about the air quality effects of smog and dust (PM10, particulate matter 10 microns or less in diameter) emissions from farm machinery and vehicle use. Growers in California are looking at CT as a possible way to reduce their operating costs. Estimates from the Conservation Technology Information Center (CTIC, 1998) showed that by switching to CT, a U.S. grower can save as much as 225 labor hours and 1750 gallons of fuel per year on just 500 acres. Machinery would be used less, and that would mean an additional savings of an estimated $\$ 2500$ in machinery wear.

Conservation tillage is an umbrella term that encompasses many types of tillage and residue management systems (Reicosky and Allmaras, 2003). There are several definitions for CT. For example, Allmaras and Dowdy (1985) define it as "a combination of cultural practices that result in the protection of soil resources while crops are grown." The Conservation Technology Information Center (CTIC) defines CT as any tillage and planting system that leaves at least 30 percent of the soil surface covered by residue after planting. California's CT Workgroup characterizes it as a crop production system that deliberately reduces or eliminates primary intercrop tillage operations such as plowing, disking, ripping, or chiseling, and that manages surface residues so as to permit efficient planting, pest management, and harvesting.

Several U.S. states have developed innovative tillage systems that conserve soil and residue and maintain crop productivity. However, findings in these states do not transfer directly to California because of differences in climatic and soil factors, dependence on irrigation and specific types of irrigation, and the overwhelming diversity of cropping systems in California. Mitchell et al. (2005) estimated that less than 2 percent of California's cultivated crop land is under some form of CT, based on CTIC's 
definition. By that view, the acreage under CT in California is very low in comparison to that in several other states. It is interesting to note, however, that with the advent of chemical herbicides, the concept of eliminating both tillage and cultivation from crop production had its first evaluation in a California orchard, in 1944, using a practice called "chemical fallow" (Owens, 2001).

As herbicide-tolerant crops (HTCs)—mainly cotton (Gossypium sp.) and corn (Zea mays L.) - have increased, so has interest in CT systems among California growers. Along with the availability of HTCs, several other factors including increased fuel prices, access to better CT, global positioning system (GPS) technology, and environmental air quality issues have had the combined effect of increasing interest in CT systems in California. Conservation management plans (CMPs), now required by the San Joaquin Valley Air Pollution Control District (SJVAPCD), can include HTCs such as Roundup Ready crop varieties and the reduction or elimination of tillage as acceptable practices for dust reduction. The SJVAPCD (2004) suggests that the reduction in the number of passes and tillage that accompanies these practices can reduce soil and water losses and mitigate dust problems. Similarly, there is increased interest in testing CT systems in other non-HTC varieties such as tomatoes, wheat, oats, and dry beans in California.

Reduced tillage, however, often brings with it changes in weed species and populations, and therefore in weed-management needs, and this is a major concern for the growers who may want to adopt CT systems (Buhler et al., 1994). Phillips and Young (1973; as cited in Owens, 2001) stated that the vital factor for success of no-till row crop production is weed control, and that this depends largely on the proper use of suitable herbicides. For this reason, our focus in this publication is on the weed management issues in CT and we will suggest some techniques for the successful implementation of CT systems in California.

\section{TILLAGE AND WEED MANAGEMENT}

Tillage has been a major agricultural weed control technique for several decades, so the development of CT systems that advocate no-tillage or reduced tillage has significant implications for growers. Tillage affects weeds by uprooting, dismembering, and burying them deep enough to prevent emergence, by changing the soil environment and so promoting or inhibiting the weeds' germination and establishment, and by moving their seeds both vertically and horizontally (Clements et al., 1996; Hartzler and Owen, 1997; Swanton et al., 2000). Tillage is also used to incorporate herbicides into the soil and to remove surface residues that might otherwise impede the herbicides' effectiveness. Any reduction in tillage intensity or frequency, therefore, poses serious concerns with regard to weed management. Weed species shifts (Buhler et al., 1994; Derksen et al., 1993) and losses in crop yields as a result of increased weed densities (Blackshaw et al., 2001) have been cited as major reasons why CT systems have not enjoyed widespread adoption. Some other common concerns about weed management under CT include emergence from recently produced weed seeds that remain near the soil surface, interception of herbicides by thick surface residues, lack of disruption of perennial weeds' roots, and changes in the timing of weed emergence (Bullied et al., 2003).

Reports of weed species shifts, however, have been inconsistent. For example, Cussans (1976) reported an increase of some dicot weeds accompanying increased levels of cultivation. Conversely, Wrucke and Arnold (1985) reported similar distribution patterns for broad-leaved weeds in both CT and conventional tillage systems. Pollard et al. (1982) reported that most weeds showed no consistent response to tillage. Swanton et al. (1999) found that tillage was an important factor affecting weed 
composition: common lambsquarters (Chenopodium album) and redroot pigweed (Amaranthus retroflexus) were associated with a moldboard plow system, whereas large crabgrass (Digitaria sanguinalis) was associated with no-till. Derksen et al. (1993) suggested that changes in weed communities were influenced more by environmental factors (location and year) than by tillage system. Childs et al. (2001) stated that, over time, small-seeded annual broadleaf weeds and perennial weeds become more prevalent in no-tillage fields. Culpepper (2005), in a survey of six states (Alabama, Georgia, Florida, Missouri, North Carolina, and Texas), reported a shift towards Amaranthus species, annual grasses, winter annuals, and morningglories (Ipomoea spp.) in glyphosate-resistant cotton CT systems. Shrestha et al. (2002) concluded that long-term changes in weed flora are driven by an interaction of several factors: tillage, environment, crop rotation, crop type, and the timing and type of weed management practice.

Very little data exist on such weed community dynamics in CT under California conditions. Studies in California have shown that most black nightshade (Solanum nigrum L.) emerged from the top 1 inch of the soil (Keeley and Thullen, 1983) and that effective control of this species could be achieved with deep tillage (Roberts and Dawkins, 1967). Maximum emergence of annual morningglory (Ipomoea spp.) seeds occurred from the top 3 inches of the soil (Wilson and Cole, 1966) and a significant reduction in its population was generally observed following cultivation (Thullen and Keeley, 1994). Wright and Vargas (2003) observed increased populations of annual morningglory in cotton under reduced tillage. Further, glyphosate does not provide consistent control of pitted morningglory (Ipomoea lacunosa) and other annual morningglory species (Koger and Reddy, 2005). These findings suggest that the San Joaquin Valley cotton production systems using Roundup Ready CT technology may still have to rely on some level of cultivation for control of annual morningglory to avoid costly hand weeding. Some other problems associated with reduced tillage include the difficulty in managing perennial weeds such as nutsedge (Cyperus spp.), since control of these species requires integration of cultural, mechanical, and chemical methods (Lingenfelter and Curran, 1995; Wright and Vargas, 2003). It is clear that CT systems remain problematic in Roundup Ready cotton production systems, but CT systems have been successfully tested in Roundup Ready forage corn in some areas of the San Joaquin Valley (Tom Barcellos, personal communication).

\section{WEED SEEDBANK DYNAMICS AND CT}

Successful implementation of a CT system depends to a large extent on a good understanding of the dynamics of weed seeds in the soil seedbank. A soil's weed seedbank is the reserve of viable weed seeds present on the surface and in the soil. The seedbank consists of new seeds recently shed by weed plants as well as older seeds, some of which have persisted in the soil for several years (Dekker, 1999). Different tillage systems disturb the vertical distribution of weed seeds in the soil-in different ways (Figure 1). Studies have found that moldboard plowing buries most weed seeds in the tillage layer, whereas chisel plowing leaves most of the weed seeds closer to the soil surface (Ball, 1992). Similarly, in reduced- or no-till systems 60 to 90 percent (depending on the soil type) of the weed seeds are located in the top 2 inches of the soil (Clements et al., 1996; Pareja and Staniforth, 1985; Swanton et al., 2000). The Figure 1 graph shows that most weed seeds remain in the top 0 to 2 inches of the soil in notill systems. These seeds are at a relatively shallow emergence depth, and with suitable moisture and temperature they would seem likely to germinate and emerge more readily than those buried deeper by other tillage systems. In fact, though, weed seeds that are on the soil surface may be more readily eaten by vertebrates and invertebrates (Cromar et al., 1999), killed by weathering, and more harmed by pathogens than those buried deeper (Davis et al., 2005). Further, CT systems do not bring weed seeds 


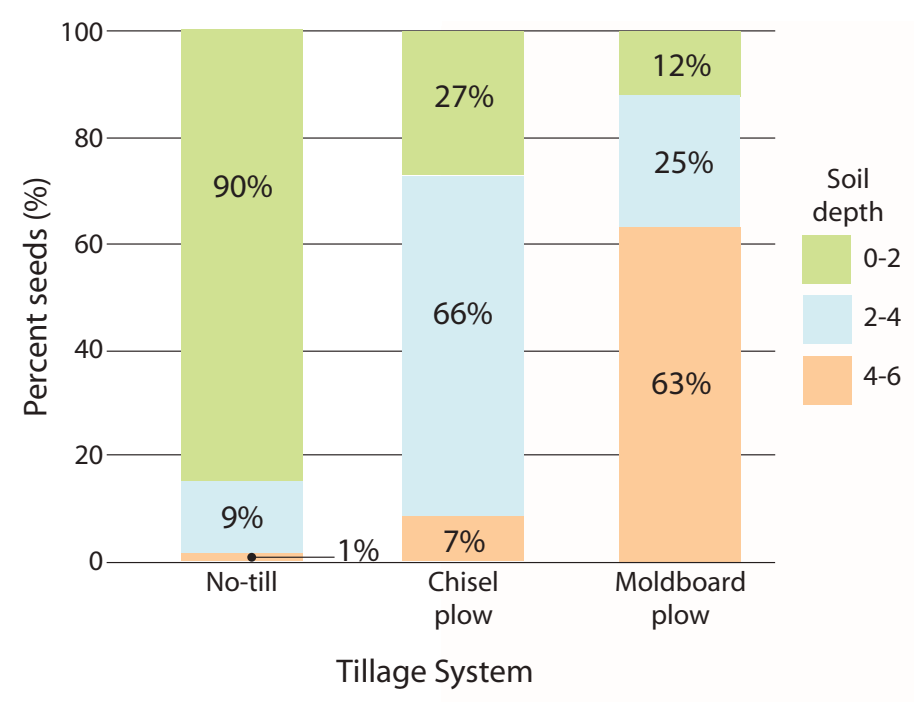

Figure 1. The vertical distribution of weed seeds in the soil profile at depths of 0 to 2 inches, 2 to 4 inches, and 4 to 6 inches (adapted from Clements et al., 1996). from deeper in the soil profile up to the soil surface. Although CT systems may have more weed seeds at shallow depths in the soil, the weed seedbank can be effectively managed by minimizing processes that replenish the weed seeds and maximizing processes that deplete the seedbank.

\section{PERENNIAL WEEDS AND CT}

Shifts in weed populations from annuals to perennials have been observed in CT systems (Derksen et al., 1993; Froud-Williams, 1998). Perennial weeds are known to thrive in reduced- or no-tillage systems (Curran et al., 1996). Most perennial weeds have the ability to reproduce from several structural organs other than seeds. For example, nutsedge and johnsongrass (Sorghum halepense), two common weed species in California, generally reproduce from underground plant storage structures: tubers (or nutlets) and rhizomes, respectively. Conservation tillage may encourage these perennial reproductive structures by not burying them to depths that are unfavorable to emergence or by failing to uproot and kill them, in contrast to conventional tillage. Most perennial weeds occur in patches, though, and mapping these perennial weed patches and attacking them regularly with herbicide applications or mechanical control (pulling, etc.) could be an effective management strategy in CT systems.

Wright and Vargas (2003) found that the most effective purple and yellow nutsedge control in cotton was achieved by a combination of glyphosate in a Roundup Ready system that involves mulching seed beds and cultivating two or three times using sweep-type cultivators. Similarly, Shrestha et al. (2003) found that cultivation was necessary for successful control of field bindweed (Convolvulus arvensis L.) in CT blackeye beans (Figure 2). All of this means that some level of cultivation may be necessary for the management of "difficult-to-control" perennial weeds in certain cropping systems in California.
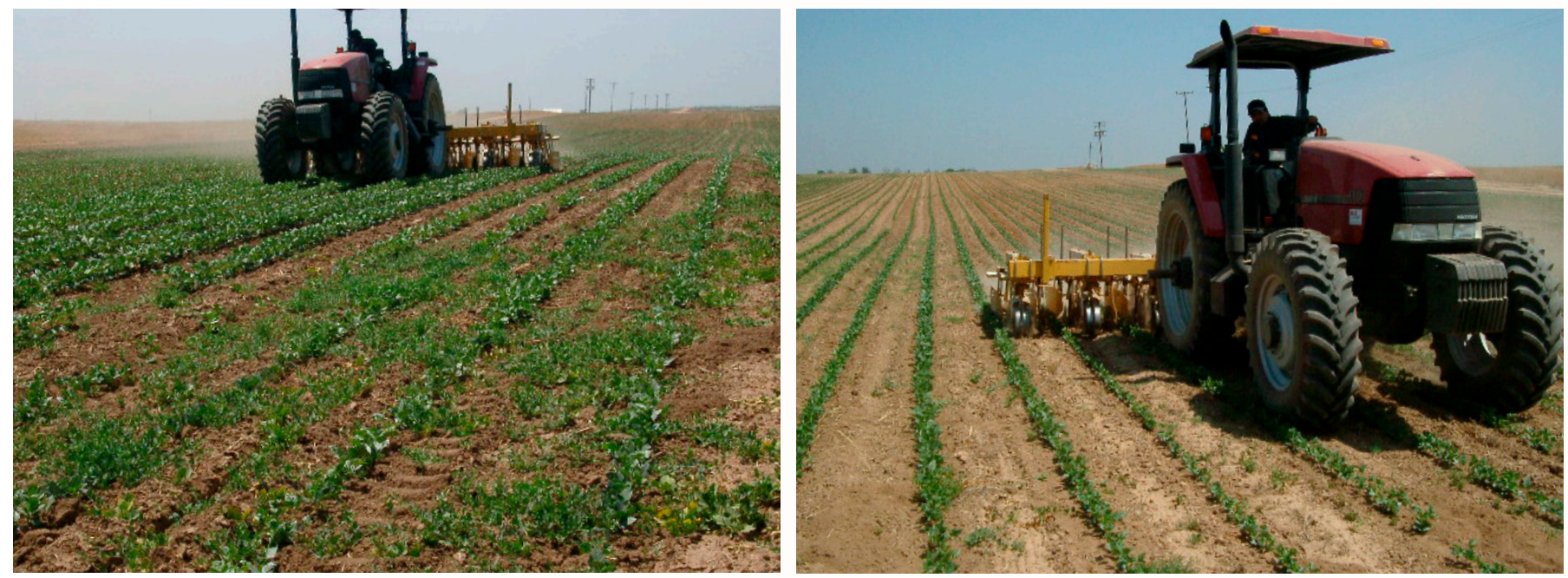

Figure 2. Successful elimination of field bindweed and other weeds in CT blackeye bean with cultivation in a CT system. Before cultivation (left) and after cultivation (right). Photos by D. Cordova. 

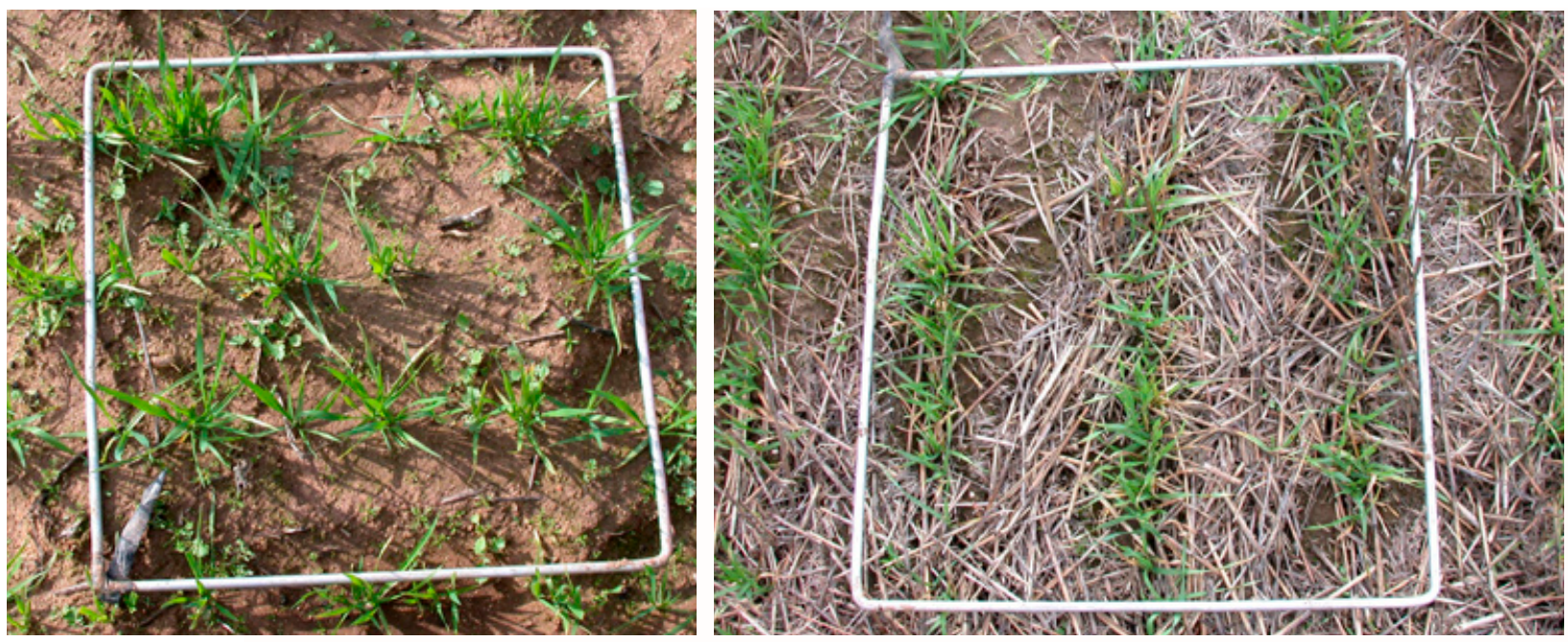

Figure 3. Comparison of wild radish emergence in conventional (left) and CT (right) plots in a small grain field in Denair, California. Photos by A. Shrestha.

\section{WEED EMERGENCE AND TIMING OF WEED MANAGEMENT OPERATIONS}

Several studies have shown the composition of weed species and their relative time of emergence to differ between CT and soil-inverting tillage systems. Some weed seeds require scarification and disturbance for germination and emergence. Their germination and emergence may be enhanced more by the types of equipment used in soil-inverting tillage systems than by CT equipment. For example, studies in Denair, California have shown a markedly lower emergence rate for wild radish (Raphanus raphanistrum) under CT than under soil-inverting tillage (Figure 3; Shrestha et al., 2003). Studies have shown that tillage stimulates the seedling emergence of wild radish (Reeves et al. 1981).

The timing of weed emergence also seems to be species dependent. For example, Bullied et al. (2003) found that species such as common lambsquarters, field pennycress (Thlaspi arvense L.), green foxtail (Setaria viridis (L.) Beauv.), wild buckwheat (Polygonum convolvulus L.), and wild oat (Avena fatua L.) emerged earlier in CT than in conventional tillage system. However, redroot pigweed and wild mustard (Sinapis arvensis L.) emerged earlier in the conventional system than in the CT.

Furthermore, in CT systems the presence of residue on the soil surface may influence soil temperature and moisture regimes that affect weed seed germination and emergence patterns over the growing season (Bullied et al., 2003; Spandl et al., 1998; Teasdale and Mohler, 2000); this may mean that CT practitioners have to change the timing of weed control measures in order to ensure their effectiveness. Soil surface residues can interfere with the application of herbicides, so there is a greater likelihood of weed escapes if residue is not managed properly or if herbicide application timings or rates are not adjusted.

\section{HERBICIDE USE AND CT}

\section{Burndown Herbicides}

Weeds that are present when crops are planted in a CT system will likely need to be controlled with a non-selective burndown herbicide such as glyphosate, paraquat, or glufosinate. Selective herbicides are not typically used for burndown in CT systems, since the objective prior to crop emergence is total vegetation control, and selective herbicides may not control all of the weeds present. For example, common chickweed 
(Stellaria media), shepherdspurse (Capsella bursa-pastoris), London rocket (Sisymbrium irio), filaree (Erodium spp.), mustards (Brassica spp.), and fiddlenecks (Amsinckia spp.) are common annual weeds that are present on the fallow beds and early cotton stands in CT systems, and these need to be controlled with non-selective postemergence herbicides (Vargas and Wright, 2005).

The nonselective burndown herbicide can be applied before or after crop planting but prior to crop emergence (Hartzler and Owen, 1997). Since these herbicides lack residual activity, applications should be scheduled as close to crop planting or emergence as the label will permit in order to minimize further weed emergence prior to crop emergence. Occasionally a burndown herbicide is tank mixed with a residual herbicide; the burndown herbicide is intended to control the emerged weeds and the residual herbicide to prevent weed emergence or growth. These burndown herbicides are usually tank mixed with carfentrazone (Shark) or oxyfluorfen (Goal) to control broadleaf weeds. Growers using CT may see this burndown herbicide application as an increase in production costs, considering that tillage would have controlled these emerged weeds in a conventional system. However, they may be overlooking cost savings for fuel, labor, and energy that are realized when a grower practices CT.

\section{Preemergence Herbicides}

In conventional tillage systems, crop residues generally are not present at the time of preemergence herbicide application. In CT systems, however, residues may be present at the time of herbicide application and may decrease the herbicide's effectiveness as the residues intercept the herbicides, reducing the amount of herbicide that can reach and kill germinating weed seeds (Hartzler and Owen, 1997). Since most preemergence herbicides can be surface applied and then incorporated into the soil by rain water or sprinkler irrigation, incorporation should not be an issue in CT systems. It may be that the increased organic matter on the soil surface binds up some of the herbicide, so a grower may need to increase application rates in order to achieve adequate control. Cover crops left on the surface present a different situation for preemergence herbicides. Cover crop mulches are seldom uniform; it is common to see thick mulch and bare ground in the same field. Researchers have observed that in areas with a thick mulch, the mulch may block an herbicide from reaching underlying weeds but may be sufficient by itself to control weeds, whereas in areas of the same field where the mulch is thin or nonexistent, the herbicide can reach the weeds and provide effective control (Lanini et al. 1989). A planter implement also moves mulch and crop residue away from the seed line, creating a relatively clean zone for good herbicide action where it is needed most.

\section{Postemergence Herbicides}

Postemergence herbicides work equally well in CT and conventional tillage systems, though it should be noted that residues on the soil surface in a CT system may interfere with effective herbicide contact with emerging seedlings. Hartzler and Owen (1997) suggest that growers wait until weeds become established and then control them with postemergence herbicides since the timing of weed emergence is less uniform in CT than in conventional systems. A grower should not wait too long to apply treatment, however; weeds that emerge together with the crop may cause greater yield losses than those that emerge later in the growing season. Similarly, crop emergence and development may be less uniform in CT systems than in conventional tillage systems, particularly for plantings made during cool periods of the year and in fields that have a lot of surface residue.

In spring and summer plantings, growers can expect this difference in weed emergence timing to be much less. Adoption of CT has increased as a result of the 
development of HTCs that allow postemergence herbicides to be applied during the growing season with a relatively low risk of crop injury. However, when postemergence herbicides are to be aerially applied, growers should not wait so long as to allow the crop canopy to close, since the crops might then intercept the aerially applied herbicide, reducing the contact between the herbicide and the weeds under the crop canopy. Correct identification of the best time frame for postemergence herbicide application is critical in CT systems. Again, the complexity of cropping systems in California makes it difficult to provide a blanket recommendation on the optimal time frame for application.

\section{Residual Activity of Herbicides}

Increased persistence of residual herbicides may be a concern in CT systems. For example, Vargas and Wright (1994) observed crop injury that was attributable to the persistence of prythiobac sodium (Staple) in a CT study. Staple was applied to cotton but the following tomato and corn crops suffered considerable stand loss due to herbicide carryover (Figure 4). Among the tillage systems compared, injury was most severe in the completely no-till system. Similar carryover of another herbicide, sulfonylurea (Accent), applied in corn caused crop injury in the subsequent wheat crop. In the absence of the soil mixing that usually comes with tillage, residual herbicides may not be diluted sufficiently in the soil profile, and this may lead to injury of the subsequent crop. When selecting herbicides for a CT system, then, it is important to make choices that minimize losses to subsequent crops in the rotation. Some herbicides, such as Smetolachlor (Dual Magnum), are less likely to persist into the following crop.

\section{HERBICIDE-TOLERANT CROPS AND CT}

Herbicide-tolerant crops (HTCs) have made it easier for growers to begin to transition to CT systems in California and other states. The advantage of HTCs, mainly Roundup Ready crops, is the ease with which a grower can apply glyphosate over the top of the crop with excellent crop safety and weed control. As a result, production costs have also decreased as growers reduce the number of trips across the field, herbicide applications, cultivations, and hand weeding operations. By reducing cultivation and eliminating hand weeding, growers have reduced their costs by $\$ 25$ to $\$ 150$ per acre depending upon weed species and density. UCCE cotton cost studies indicate an average savings of $\$ 60$ per acre with Roundup Ready cotton compared to the costs of

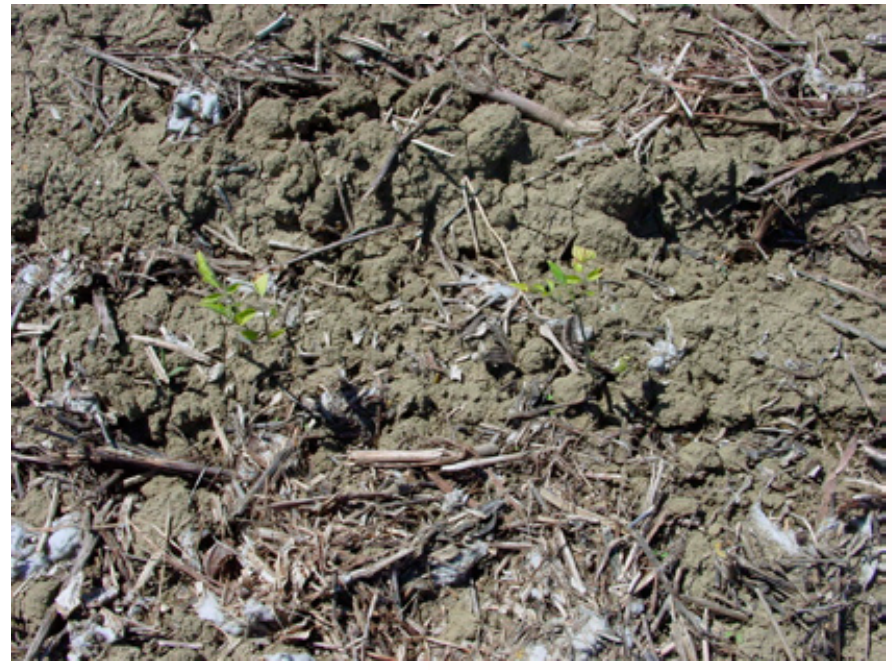

Figure 4. Injury to tomato by the carryover of the herbicide Staple from cotton in a CT plot at Five Points, California. Photo by R. Vargas growing conventional cotton (UCCE, 2003).

The potential for weed resistance to specific herbicides is always a concern with herbicide programs, and that concern increases with HTCs in a CT system. Roundup Ready promotes the continuous use of glyphosate, and we probably can expect that to induce shifts in weed species or the development of glyphosate-resistant weeds in HTC fields. Glyphosate-resistant horseweed or marestail, (Conyza canadiensis) has been reported in no-till Roundup Ready corn-soybean rotations in the Midwest and mid-Atlantic regions of the United States (Mueller et al., 2003), in the cotton producing areas of the mid-South (Hayes and Steckel, 2005), and recently in California on canal banks with a history of repeated glyphosate use (Shrestha and Hembree, unpublished). The elimination of tillage takes away an important tool for managing herbicide- 


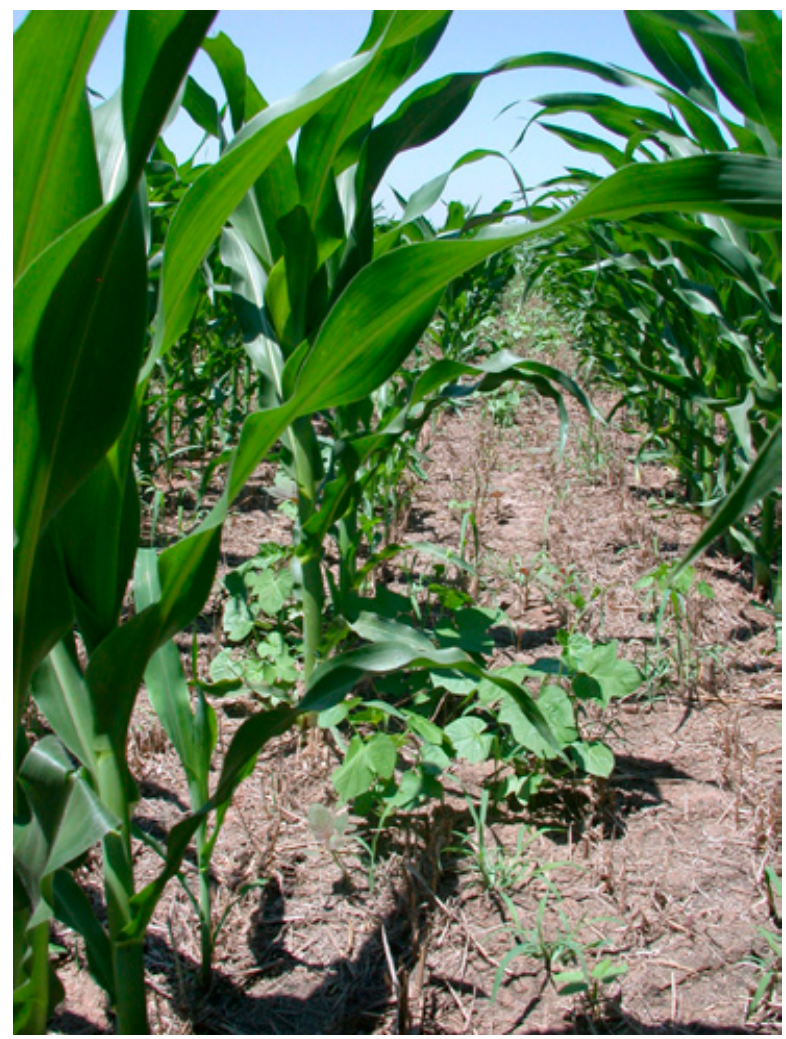

Figure 5. Annual morningglory escapes seen in a no-till Roundup Ready corn system in Tulare County. Photo by A. Shrestha. resistant weeds. Studies by Wright and Vargas (2003) in the San Joaquin Valley have already shown weed shifts in Roundup Ready fields, with increases in annual morningglory over conventional tillage plots (Figure 5). Although CT systems are most often practiced in conjunction with HTCs, conventional varieties, herbicides with different modes of action, or tillage may also be needed to manage herbicideresistant weeds.

Another concern as acreages of HTCs in CT systems increase is growers' greater reliance on postemergence herbicides applied prior to planting and during the cropping season. Herbicides such as glyphosate and carfentrazone are sometimes applied by airplane or helicopter. With more than 200 different crops grown in the San Joaquin Valley, the potential for herbicide drift and associated damage to nontarget crops is very high. Even ground applications of herbicides carry with them some risk of movement to sensitive nontarget crops. Herbicide drift management is an important issue when using HTCs in a CT system.

\section{ALTERNATIVE TECHNIQUES FOR WEED MANAGEMENT IN CT}

\section{Mulches}

Any material that blocks light will suppress or prevent the growth of weeds. Layers of organic mulches such as municipal yard waste, straw, hay, or wood chips, for example, can be used for control of annual weeds (Makus et al., 1994). Thicker layers provide better results. Organic mulches break down over time, and the original thickness can typically reduce by 60 percent after one year. Coarse green waste works better than dry organic residue as a mulch. Organic residue mulches are rarely used in vegetable production in California because they are so costly to obtain, as well as to haul and to spread. Organic mulches are used particularly in areas close to cities that have implemented programs to collect organic wastes and either to compost the material or to sell it as green waste for agricultural use.

Cover crops can be grown and then undercut and left on the same beds to form organic mulch (Lanini et al., 1989; Creamer, 1995). Plants that are used to produce this type of organic mulch include various cereals, clovers, vetches, and fava beans (Abdul-Baki and Teasdale, 1993 and 1997). Two advantages of growing the mulch in place are that it is rooted and so will not blow away in windy locations and that it does not have to be transported and spread. Organic mulches provide some weed control, depending on their thickness and ability to block light, besides offering other benefits to row crops. Thick mulches have created some difficulties in direct-seeded crop fields (Lanini et al. 1989), but less so with transplant fields.

Cover crop mulches are currently the subject of a great deal of research on crops (including processing tomatoes) in California's interior valleys, but at present their use is not widespread. Small grain cover crops are being tried by some growers in CT processing tomato fields in western Fresno County. The cover crops are planted after tomato harvest in the fall, allowed to grow over the winter, and killed in late winter with a postemergence herbicide such as glyphosate. Tomatoes are then transplanted into undisturbed or strip-tilled beds in spring. Considerable residue is present on the beds in this system (Figure 6), but this can also have the negative effect of interfering with postemergence herbicides, resulting in weed escapes. Such weed escapes have 


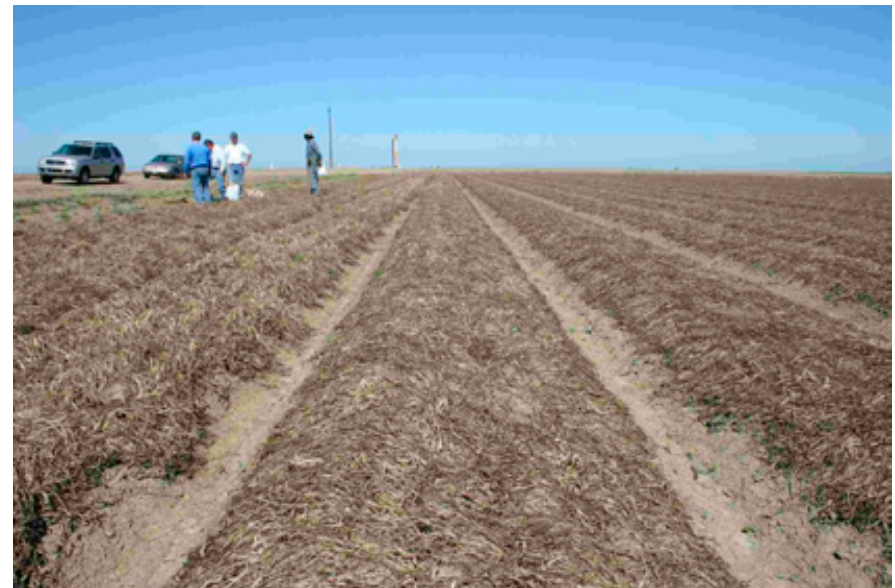

Figure 6. Residue of a small grain cover crop on beds of CT processing tomatoes in western Fresno County. Photo by A. Shrestha.

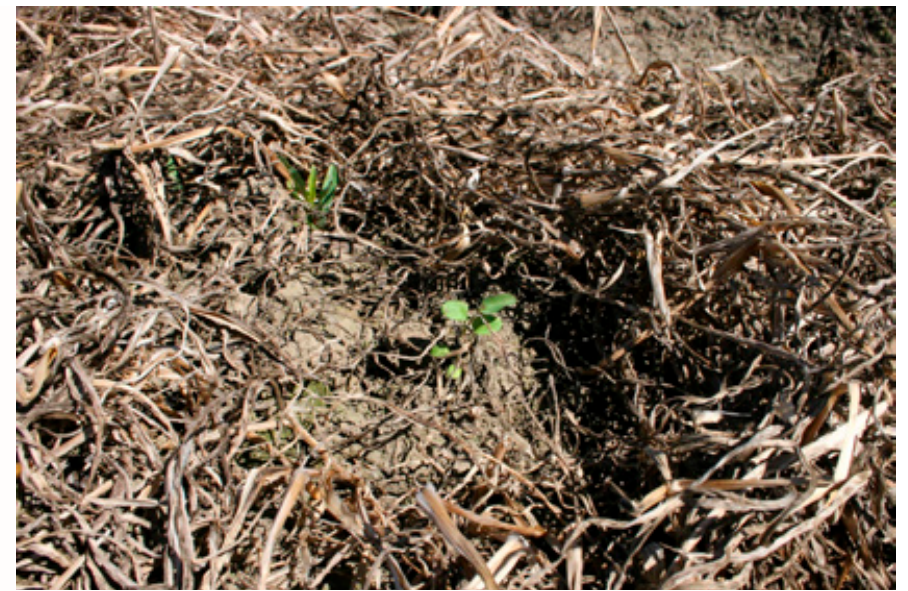

Figure 7. Postemergence herbicide weed escapes beneath the cover crop residue. The weeds survived due to shielding caused by the heavy surface residues. Photo by A. Shrestha.

been observed in a tomato CT system with small grain cover crops in Fresno County (Figure 7).

\section{Cultivation}

Tillage is a time-tested technique for control of weeds in crop production. A new generation of cultivators has been developed to remove weeds from between the seed rows, and in some situations from the seed row itself (Wallace and Bellinder, 1992). Cultivators such as brush hoes work the soil in a circular direction and so do not remove surface residues. Knives that run parallel to the soil surface and undercut weeds also preserve surface residues.

\section{Weed Burning}

Flaming is a popular method for control of weeds in organic production systems. It is used preemergence on a wide variety of crops, including peppers, carrots, onions, parsley, potato, and parsnips (Melander, 1998). Flaming is also used postemergence on young onion (Rifai et al., 1996) and garlic, or as a directed treatment at the base of more flame-tolerant crops such as corn or cotton when they are 12 or more inches tall (Schlesselman et al. 1989). Flaming is one of the more economical methods for controlling weeds in organic vegetable operations, with costs varying from $\$ 30$ to $\$ 35$ per acre depending upon how much propane is consumed in the operation (Klonsky et al., 1994). Flaming works best on small broadleaf weeds but normally does not control grasses or large weeds. Grasses are difficult to control with flaming; they have growing points at or below the soil surface, so they often recover after flaming. Large broadleaf weeds can often recover after partial top removal just because they have so many growing points.

\section{Subsurface Drip Irrigation}

Drip irrigation tape buried 6 to 12 inches below the surface of the bed can provide moisture to the crop and keep the surface too dry for weeds to germinate (Grattan et al., 1988). If properly managed, this technique can provide significant weed control during the dry periods of the year. Sutton (2004) observed that weed densities in processing tomatoes were 98 percent lower under subsurface drip irrigation than in furrow-irrigated systems. The use of subsurface drip irrigation also eliminates the need to maintain furrows for irrigation. Figure 8 illustrates the difference between weed populations in a subsurface drip tomato field and in a furrow-irrigated tomato field a few weeks after tomato transplanting. 

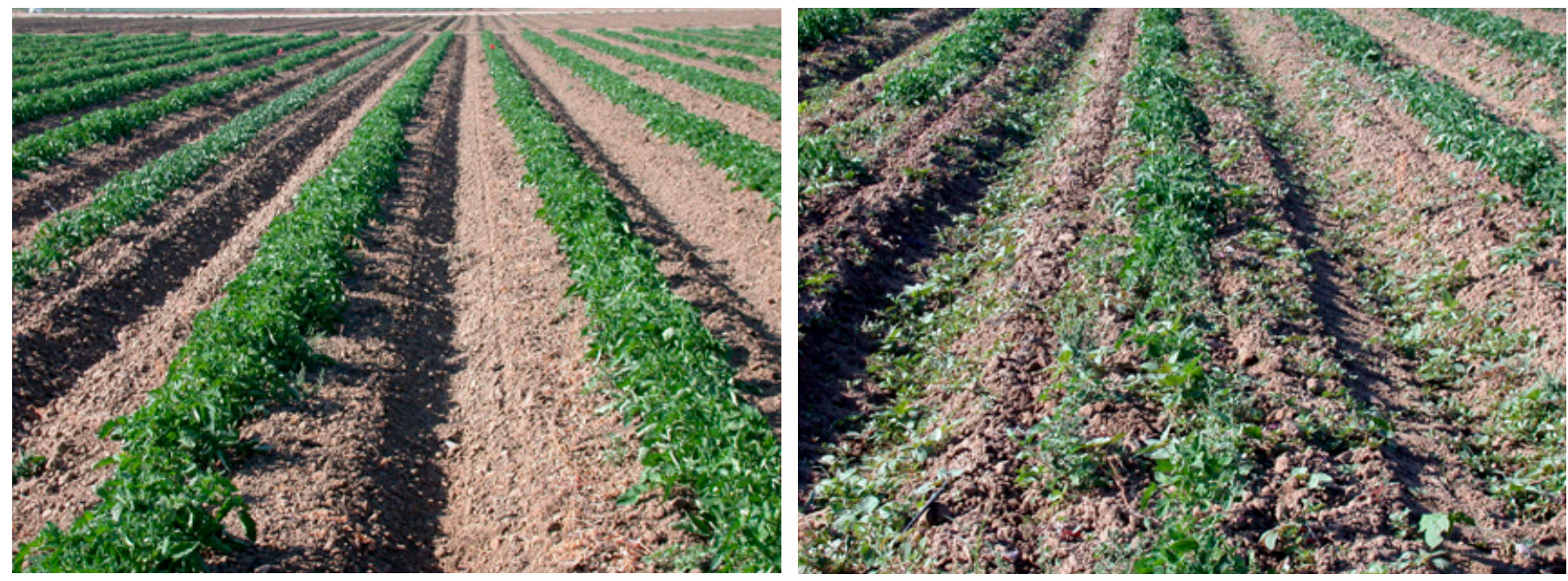

Figure 8. Weed populations in subsurface drip-irrigated (left) and furrow-irrigated (right) tomato plots in Five Points, California. Photos by A. Shrestha.

\section{SUMMARY AND CONCLUSIONS}

California has a wider variety of diverse and complex cropping systems than any other part of the United States. This means that findings on weed management in CT systems from elsewhere may not be readily applicable to California. There are several management techniques that can be applied to our conditions, however, and studies are being conducted to develop weed management techniques for CT systems in California. Conventional principles and a conventional philosophical approach for weed management still apply, though, in conservation and CT systems. Proper weed identification, effective monitoring of weed communities and patch dynamics, timely weed management operations, proper selection and rotation of herbicides, monitoring for herbicide resistance, and minimizing weed seed return all are just as essential in CT as in conventional systems. Some alternative techniques to manage weeds are also available. Growers may have to adjust some aspects of a CT system to facilitate weed management; for example, hard-to-control weeds such as annual morningglory in cotton and perennial weeds may still require cultivation. Proper weed management is essential for the success of a CT system.

\section{REFERENCES}

Abdul-Baki, A. A., and J. R. Teasdale. 1993. A no-tillage tomato production system using hairy vetch and subterranean clover mulches. HortScience 28:106-108.

- 1997. Sustainable production of fresh-market tomatoes and other summer vegetables with organic mulches. Farmer's Bulletin No. 2279. Rev. Aug. 1997 USDA-ARS. Beltsville, MD: USDA-ARS, Beltsville Agric. Res. Ctr., West.

Allmaras, R. R., and R. H. Dowdy. 1985. Conservation tillage systems and their adoption in the United States. Soil Till. Res. 5:197-222.

Ball, D. A. 1992. Weed seed bank response to tillage, herbicide, and crop rotation sequence. Weed Sci. 40:654-659.

Blackshaw, R. E., F. J. Larney, C. W. Lindwall, P. R. Watson, and D. A. Derksen. 2001. Tillage intensity and crop rotation affect weed community dynamics in a winter wheat cropping System. Can. J. Plant Sci. 81:805-813

Buhler, D. D., D. E. Stoltenberg, R. L. Becker, and J. L. Gunsolus. 1994. Perennial weed populations after 14 years of variable tillage and cropping practices. Weed Sci. 34:29-33. 
Bullied, W. J., A. M. Marginet, and R. C. Van Acker. 2003. Conventional- and conservation-tillage systems influence emergence periodicity of annual weed species in canola. Weed Sci. 51:886-897.

Carter, L. M. 1996. Tillage. In S. J. Hake, T. A. Kerby, and K. D. Hake, eds., Cotton production manual. Oakland: University of California, Division of Agriculture and Natural Resources Publ. 3352. 175-186.

Childs, D., T. Jordan, M. Ross, and T. Bauman. 2001. Weed control in no-tillage systems. Purdue University Cooperative Extension Service. Conservational Tillage Series CT-2. West Lafayette: Purdue University.

Clements, D. R., D. L. Benoit, S. D. Murphy, and C. J. Swanton. 1996. Tillage effects on weed seed return and seed bank composition. Weed Sci. 44:314-322.

Conservation Tillage Information Center (CTIC). 1998. National survey of conservation tillage practices. West Lafayette: Conservation Tillage Information Center.

Creamer, N. G., B. Plassman, M. A. Bennett, R. K. Wood, B. R. Stinner, and J. Cardina. 1995. A method for mechanically killing cover crops to optimize weed suppression. Am. J. Alt. Agric. 10:157-162.

Cromar, H. E., S. D. Murphy, and C. J. Swanton. 1999. Influence of tillage and crop residue on postdispersal predation of weed seeds. Weed Sci. 47:184-194

Culpepper, A. S. 2005. Weed shifts and volunteer crops in Roundup Ready systems. Proc. Belt. Cotton Conf., Jan. 4-7, New Orleans. 3160.

Curran, W. S., D. D. Lingenfelter, and L. Garling. 1996. An introduction to weed management for conservation tillage systems. Conservation Tillage Series No. 2. College of Agricultural Sciences, Cooperative Extension. University Park, PA: The Pennsylvania State University.

Cussans, G. W. 1976. The influence of changing husbandry on weeds and weed control in arable crops. In Proc. Brit. Crop Prot. Conf.-Weeds, Brighton, UK. 1001-1008.

Davis, A., K. Renner, C. Sprague, L. Dyer, and D. Mutch. 2005. Integrated Weed Management: One Year's Seeding... . East Lansing: Michigan State University. Extension Bulletin E-2931.

Dekker, J. 1999. Soil weed seed banks and weed management. J. Crop Prod. 2:139-166.

Derksen, D. A., G. P. Lafond, A. G. Thomas, H. A. Loeppky, and C. J. Swanton. 1993. Impact of agronomic practices on weed communities: Tillage systems. Weed Sci. 41:409-417.

Edwards, W., and D. Smith. 2005. 2005 Iowa custom farm rate survey. Ames: Iowa State University. Available online: http://www.extension.iastate.edu/publications/FM1698.pdf

Froud-Williams, R. J. 1988. Changes in weed flora with different tillage and agronomic management systems. In M. A. Altieri and M. Liebman, eds., Weed Management in Agroecosystems: Ecological Approaches. Boca Raton: CRC Press. 213-236.

Grattan, S. R., L. J. Schwankl, and W. T. Lanini. 1988. Weed control by subsurface drip irrigation. Calif. Agric. 42(3):22-24.

Hartzler, R. G., and M. D. Owen. 1997. Weed management in conservation tillage systems. Ames: Iowa State University, University Extension. Available online: http://www.extension.iastate.edu/Publications/PM1176.pdf

Hayes, R. M., and L. E. Steckel. 2005. Glyphosate-resistant weeds: current problems, potential problems. Proc. Belt. Cotton Conf. 3161-3162. 
Keeley, P. E., and R. J. Thullen. 1983. Influence of planting date on the growth of black nightshade (Solanum nigrum). Weed Sci. 31:180-184.

Klonsky, K., L. Tourte, D. Chaney, P. Livingston, and R. Smith. 1994. Cultural practices and sample costs for organic vegetable production on the Central Coast of California. Oakland: University of California, Division of Agriculture and Natural Resources. Giannini Foundation Information Series No. 94-2.

Koger, C. H., and K. N. Reddy. 2005. Glyphosate efficacy, absorption, and translocation in pitted morningglory (Ipomoea lacunosa). Weed Sci. 53:277-283.

Lanini, W. T., D. R. Pittenger, W. L. Graves, F. Munoz and H. S. Agamalian. 1989. Subclovers as living mulches for managing weeds in Vegetables. Calif. Agric. 43:25-27.

Lingenfelter, D. D., and W. S. Curran. 1995. Controlling yellow nutsedge in agronomic crops (an integrated approach). Agronomy Facts. 47. C. College of Agricultural Sciences, Cooperative Extension, University Park: The Pennsylvania State University.

Makus, D. J., S. C. Tiwari, H. A. Pearson, J. D. Haywood, and A. E. Tiarks. 1994. Okra production with pine straw mulch. Agroforestry Systems 27:121-127.

Melander, B. 1998. Interaction between soil cultivation in darkness, flaming, and brush weeding when used for in-row weed control in vegetables. Biol. Agric. and Hort. 16:1-14.

Mitchell, J. P., S. R. Temple, A. Shrestha, and J. Beyer. 2005. Conservation tillage corn, cotton and tomato systems in California. Proc. 27th Ann. Southern Cons. Tillage Syst. Conf., June 27-29, Clemson University, Florence, SC. p. 14.

Mueller, T. C., J. H. Massey, R. M. Hayes, C. L. Main, and C. Neal Stewart, Jr. 2003. Shikimate accumulates in both glyphosate-sensitive and glyphosateresistant horseweed (Conyza canadiensis L. Cronq.). J. Agric. Food Dem. 51:680-684.

Owens, H. 2001. Tillage: From plow to chisel and no-tillage, 1930-1999. Midwest Plan Service. Ames: Iowa State University.

Pareja, M. R., and D. W. Staniforth. 1985. Distribution of weed seed among soil structural units. Weed Sci. 33:182-189.

Phillips, S. H., and H. Young, Jr. 1973. No-tillage farming. Milwaukee: Reiman Associates.

Pollard, F., S. R. Moss, G. W. Cussans, and R. J. Froud-Williams. 1982. The influence of tillage on the weed flora in a succession of winter wheat crops on a clay loam soil and silt loam soil. Weed Res. 22:129-136.

Reeves, T. G., G. R. Code, and C. M. Piggin. 1981. Seed production and longevity, seasonal emergence and phenology of wild radish (Raphanus raphanistrum L.). Aust. J. Exp. Agric. Anim. Husb. 21:524-530.

Reicosky, D. C., and R. R. Allmaras. 2003. Advances in tillage research in North American cropping systems. J. Crop Prod. 8:75-125.

Rifai, M. N., M. Lacko-Bartosova, and V. Puskarova. 1996. Weed control for organic vegetable farming. Rostlinna Vyroba 42:463-466.

Roberts, H. A., and P. A. Dawkins. 1967. Effect of cultivation on the numbers of viable seeds in soil. Weed Res. 7:290-301.

San Joaquin Valley Air Pollution Control District (SJVAPCD). 2004. List of conservation management practices. May, 20, 2004. Available online: http://www.valleyair.org/farmpermits/applications/cmp/cmp_list.pdf 
Schlesselman, J. T., G. L. Ritenour, and M. S. Hile. 1989. Cultural and physical control methods. In E. A. Kurtz and F. O. Colbert, eds., Principles of weed control in California. Fresno: Thomson Publications. 45-60.

Shrestha, A., S. Z. Knezevic, R. C. Roy, B. Ball-Coelho, and C. J. Swanton. 2002. Effect of tillage, cover crop and crop rotation on the composition of weed flora in a sandy soil. Weed Res. 42:76-87.

Shrestha, A., R. Vargas, J. Mitchell, and D. Cordova. 2003. Initial experiences in transition from conventional to conservation tillage: A farming systems perspective. Proc. Cons. Tillage 2003: The California Experience. Oct. 7-9, Tulare, Five Points, Davis, California.

Spandl, E., B. R. Durgan, and F. Forcella. 1998, Tillage and planting date influence foxtail (Setaria spp.) emergence in continuous spring wheat (Triticum aestivum): Weed Technol. 12:223-229.

Sutton, K. F. 2004. Weed control, yield and economics of processing tomato (Lycopersicon esculentum) under different tillage and irrigation systems. Master's Thesis. University of California, Davis.

Swanton, C. J., A. Shrestha, S. Z. Knezevic, R. C. Roy, and B. R. Ball-Coelho. 1999. Effect of tillage systems, $\mathrm{N}$, and cover crop on the composition of weed flora. Weed Sci. 47:454-461.

- 2000. Influence of tillage type on vertical weed seedbank distribution in a sandy soil. Can. J. Plant Sci. 80:455-457.

Swanton, C. J., A. Shrestha, D. R. Clements, B. D. Booth, and K. Chandler. 2002. Evaluation of alternative weed management systems in a modified no-tillage corn-soybean-winter wheat rotation: Weed densities, crop yields, and economics. Weed Sci. 50:505-511.

Teasdale, J. R., and C. L. Mohler. 2000. The quantitative relationship between weed emergence and the physical properties of mulches: Weed Sci. 48 385-392.

Thullen, R. J., and P. E. Keeley. 1994. Control of ivyleaf morningglory (Ipomoea hederacea) in cotton (Gossypium hirsutum) by combinations of methods. Weed Tech. 8:772-776.

University of California Cooperative Extension (UCCE). 2003. Sample costs to produce cotton: Transgenic herbicide-resistant Acala variety. Available online: http://www.agecon.ucdavis.edu/outreach/crop/cost-studies/CottonTrans03.pdf.

Vargas, R. N., and S. D. Wright. 1994. Staple plant back studies. Cotton Weed Management Research Progress Report. University of California Cooperative Extension, Madera and Tulare Counties.

- 2005. UC IPM pest management guidelines: Cotton. Statewide IPM Program. Oakland: Division of Agriculture and Natural Resources, University of California Publication 3444.

Wallace, R. W., and R. R. Bellinder. 1992. Alternative tillage and herbicide options for successful weed control in vegetables. HortScience 27:745-749.

Wilson, H. P., and R. H. Cole. 1966. Morningglory competition in soybeans. Weed Sci. 14:49-51.

Wright, S. D., and R. N. Vargas. 2003. Integrating weed management tools in cotton and corn: GMOs and conventional herbicides. Proc. California Weed Sci. Soc. 55:117-122.

Wrucke, M. A., and W. E. Arnold. 1985. Weed species distribution as influenced by tillage and herbicides. Weed Sci. 33:853-856. 


\section{FOR MORE INFORMATION}

You'll find related information in these titles and in other publications, slide sets, CD-ROMs, and videos from UC ANR:

Minimum Tillage Vegetable Crop Production in California, Publication 8132

Alive and Well: Sustainable Soil Management, Video V92-D

Pests of the Garden and Small Farm, Publication 3332

To order these products, visit our online catalog at http://anrcatalog.ucdavis.edu. You can also place orders by mail, phone, or FAX, or request a printed catalog of publications, slide sets, CD-ROMs, and videos from

University of California

Agriculture and Natural Resources

Communication Services

6701 San Pablo Avenue, 2nd Floor

Oakland, California 94608-1239

Telephone: (800) 994-8849 or (510) 642-2431

FAX: (510) 643-5470

E-mail inquiries: danrcs@ucdavis.edu

An electronic version of this publication is available on the ANR Communication Services Web site at http://anrcatalog.ucdavis.edu.

Publication 8200

ISBN-13: 978-1-60107-392-1

ISBN-10: 1-60107-392-5

This publication has been anonymously peer reviewed for technical accuracy by University of California scientists and other qualified professionals. This review process was managed by the ANR Associate Editor for Agronomy and Range Sciences.

C 2006 by the Regents of the University of California

Division of Agriculture and Natural Resources.

All rights reserved.

The University of California prohibits discrimination or harassment of any person on the basis of race, color, national origin, religion, sex, gender identity, pregnancy (including childbirth, and medical conditions related to pregnancy or childbirth), physical or mental disability, medical condition (cancer-related or genetic characteristics), ancestry, marital status, age, sexual orientation, citizenship, or status as a covered veteran (covered veterans are special disabled veterans, recently separated veterans, Vietnam era veterans, or any other veterans who served on active duty during a war or in a campaign or expedition for which a campaign badge has been authorized) in any of its programs or activities.

University policy is intended to be consistent with the provisions of applicable State and Federal laws.

Inquiries regarding the University's nondiscrimination policies may be directed to the Affirmative Action/Staff Personnel Services Director, University of California, Agriculture and Natural Resources, 1111 Franklin Street, $6^{\text {th }}$ Floor, Oakland, CA 94607, (510) 987-0096. For information about obtaining this publication, call (800) 994-8849. For downloading information, call (530) 297-4445.

pr-12/06-WJC/CAM

To simplify information, trade names of products have been used. No endorsement of named or illustrated products is intended, nor is criticism implied of similar products that are not mentioned or illustrated. 